\title{
Para além das narrativas sobre concubinagem: gênero, escravidão e liberdade no Caribe francês (séculos XVIII e XIX)
}

\author{
Letícia Gregório Canelas ${ }^{1}$
}

Resumo: Em diferentes zonas de contato nas sociedades escravistas da América e do Caribe, histórias sobre relações entre mulheres negras escravizadas e homens de origem europeia, geralmente seus senhores, foram mencionadas em relatos de viajantes e de missionários, na literatura e em documentos oficiais, em geral, escritos por homens brancos. As imagens construídas sobre as mulheres são frequentemente estereotipadas e suas experiências e atuações invisibilizadas por essas narrativas, o que fomentou a construção de uma imagem racializada e depreciativa sobre as mulheres negras do Caribe francês, sobretudo a partir do discurso frequente que vinculou alforria e mestiçagem. Neste artigo, visando demonstrar as limitações e os estereótipos presentes nas fontes escritas por homens brancos, exponho resultados de minha pesquisa sobre a conquista da alforria na Martinica no século XIX, em uma abordagem de história social, procurando demonstrar alguns indícios de experiências de mulheres negras escravizadas nas Antilhas Francesas e suas lutas por sua liberdade e de suas famílias. Desse modo, busco evidenciar a fragilidade do argumento o qual afirma que a mulher negra escravizada teve acesso a sua alforria e de seus filhos predominantemente por meio de suas relações afetivas (e desiguais) com os homens brancos.

Palavras-chave: Escravidão, Alforria, Gênero, Caribe Francês.

\section{Beyond narratives about concubinage: gender, slavery, and freedom in the French Caribbean of the 18th and 19th century}

\begin{abstract}
In slave societies throughout the Americas and the Caribbean, travel reports, literature, and official documents frequently reported intimate relationships between enslaved black women and men of European descent - typically their masters. Most of these stories were written by white men, and Black women were usually stereotyped. The narratives also rendered their experiences and actions invisible, resulting in a derogatory image of black women in the French Caribbean that juxtaposed manumission and miscegenation, suggesting that they got freedom through intimacy. The purpose of this article is to demonstrate the limitations and stereotypes evident in the sources written by white men, as opposed to the actions of Black women to achieve manumission in Martinique during the nineteenth century. From a social history perspective, my research describes the experiences of black women enslaved in the French Antilles and their struggle for freedom, as well as that of their families. This highlights the fragility of the argument that enslaved black
\end{abstract}

\footnotetext{
1 Doutora em História Social pela Universidade Estadual de Campinas. Professora colaboradora (edital PART) e Pesquisadora de Pós-Doutorado do Departamento de História da Universidade de São Paulo e (FFLCH - USP). E-mail: leticiacanelas@usp.br.ORCID: 0000-0002-9667-6317
} 
women were able to gain their freedom, as well as that of their children, through intimate (and unequal) relationships with white men.

Keywords: Slavery, Manumission, Gender, French Caribbean.

Artigo recebido em: 31/08/2021

Artigo aprovado para publicação em: 11/10/2021

\section{Introdução}

Em diferentes zonas de contato nas sociedades escravistas da América e do Caribe, desde o século XVII, histórias sobre relações entre uma mulher negra (escravizada ou liberta) e um homem de origem europeia foram mencionadas em relatos de viajantes e de missionários, na literatura e em documentos oficiais, em geral, escritos por homens brancos. De acordo com Mary Louise Pratt, "sexo e escravidão" se tornaram grandes temas das narrativas de viagem e da literatura a partir da década de 1760, ou ainda, "um único grande tema, pois os dois aparecem invariavelmente unidos nas narrativas alegóricas que invocam o amor conjugal como uma alternativa à escravização e à dominação colonial, ou como versão recém-legitimada destas" (PRATT, 1999, p. 155). Algumas histórias se tornaram célebres, como aquelas do viajante escocês John Stedman e sua escrava Joana, no Suriname (PRATT, 1999, p. 164-182), e a história de Chica da Silva e o contratador de diamantes João Fernandes de Oliveira, no Brasil (FURTADO, 2003).

Doris Garraway demonstra que histórias similares estiveram presentes nas narrativas coloniais sobre as Antilhas Francesas desde meados do século XVII, embora tenham se transformado significativamente em relação aos temas, autoria e orientação ideológica até o final do século XVIII. De acordo com a autora, missionários, escritores e viajantes constantemente usaram os termos libertine (libertina) e libertinage (libertinagem) para descrever as colônias francesas como locais de imoralidade, heresia religiosa, violência e licença sexual. Na retórica colonial acerca da "libertinagem", observa-se a ideia de que a intimidade inter-racial era subversiva para a ordem social nas colônias. 
Nesse sentido, a legislação discriminatória produzida no Caribe francês entre os séculos XVII e XVIII representou os "livres de cor" como filhos ilegítimos dos homens brancos com mulheres negras escravas, expressando as inquietudes da classe dominante sobre a "libertinagem inter-racial”. De acordo com Garraway, ao tornar as crianças mestiças ilegítimas um tabu, o discurso jurídico, e colonial em geral, definiu os "mulatos", sobretudo os livres, em termos de “imoralidade, concupiscência e selvageria sexual", assim como figuras "impuras”, capazes de poluir a sociedade branca se lhes fosse permitido qualquer privilégio da elite social, cargos políticos, ou ligações conjugais com os brancos. Em sua análise, expõe conclusões pertinentes sobre o processo de construção do discurso que inter-relaciona "mestiçagem" e "libertinagem", o qual teria afetado a classe dos livres de cor durante o período colonial, sobretudo as mulheres afrodescendentes, assegurando a hegemonia tanto sexual como política dos homens brancos (GARRAWAY, 2005, p. 28-33).

Experiências e narrativas como aquelas abordadas por Doris Garraway, Mary Louise Pratt e outras pesquisadoras (FURTADO, 2008; WINTERS, 2006; CÂNDIDO, 2012) marcaram o imaginário sobre as "escravas concubinas" no Mundo Atlântico, que (supostamente) teriam conquistado suas liberdades, e também de seus filhos, quase que exclusivamente por conta das relações afetivas com seus senhores brancos. Dessa forma, nas sociedades escravistas do Caribe francês, entre os séculos XVIII e XIX, embora possamos observar muitas mulheres africanas e afrodescendentes, escravizadas e libertas, como trabalhadoras responsáveis por atividades variadas, desde as domésticas àquelas relacionadas às economias informais, e como arrimos de famílias, dando sustentação a filhos, maridos e outros parentes agregados, os quadros e axiomas que prevalecem são especialmente aqueles que as descrevem como amantes e concubinas. Mesmo que tivessem uma vida amorosa intensa e muitos filhos, a questão é que a presença das mulheres negras, quando registrada em documentos, passa pela lente de registro do olhar branco, europeu e masculino, observando-as sobretudo em função dos homens, fossem maridos, amantes ou senhores: ou são retratadas como mães e/ou esposas de família - neste caso, quando casadas oficialmente, situação mais esporádica entre escravas e libertas no Caribe francês - ou como promíscuas, 
altamente sexualizadas, exercendo seu poder por meio da sedução. Seu trabalho e sua atuação na comunidade negra e escravizada e em suas famílias, sobretudo em relação à conquista de autonomia e independência, construindo um caminho para a liberdade, se não são ignoradas, são menosprezados nas análises sobre mobilidade social e transformações dentro do sistema escravista.

Essa visão se tornou preponderante a partir de diversas fontes produzidas entre os séculos XVII e XIX, entre relatos de viagem e escritos de missionários, diários de colonos e documentos administrativos e oficiais, no mundo atlântico francês. As imagens construídas sobre as mulheres são frequentemente estereotipadas e suas experiências e atuações invisibilizadas por essas narrativas, o que fomentou a construção de uma imagem racializada e potencialmente depreciativa sobre as mulheres negras do Caribe francês, sobretudo a partir do discurso frequente que vinculou alforria e mestiçagem.

Neste artigo, visando demonstrar as limitações e os estereótipos presentes nas fontes escritas por homens brancos, exponho resultados de minha pesquisa sobre a conquista da alforria na Martinica, em uma abordagem histórico-social, procurando demonstrar alguns indícios de experiências de mulheres negras escravizadas nas Antilhas Francesas e as lutas por sua liberdade e de suas famílias. Desse modo, busco evidenciar a fragilidade do argumento o qual afirma que a mulher africana e afrodescendente escravizada teve acesso a sua alforria e de seus filhos predominantemente por meio de suas relações afetivas (e desiguais) com os homens brancos.

\section{Olhares brancos sobre mulheres negras, alforria e concubinagem}

Os discursos hegemônicos construídos pela elite branca, pela administração colonial e por viajantes e cronistas europeus acerca da alforria das pessoas escravizadas no Caribe francês revelam questões profundas sobre raça e gênero. A racialização da escravidão — ou ainda, a identificação entre fenótipo e lugar social hierarquicamente estruturado — induziu o recrudescimento de hierarquias raciais e o desenvolvimento do preconceito de cor, que se fortaleceram tanto nas colônias como na metrópole entre os séculos XVIII e XIX. Os discursos produzidos acerca das origens da classe dos livres de cor durante todo o período escravista contribuíram de maneira fundamental no desenvolvimento de práticas e ideologias de dominação nas colônias francesas e de 
restrições à mobilidade social e econômica ascendentes dos afrodescendentes livres e libertos. O processo de construção da narrativa que inter-relaciona mestiçagem, libertinagem e liberdade afetou os indivíduos livres e libertos ao longo do período colonial e escravista, sobretudo as mulheres negras. Observadas como vetores da origem e do aumento da classe de "mulatos" e libertos, sobre elas se fomentou uma imagem moralmente racializada e depreciativa (CANELAS, 2020).

A questão das barreiras e hierarquias raciais se entrelaça com o tema da alforria devido ao fato deste fenômeno permitir o crescimento da classe dos livres de cor, que a elite branca e o governo colonial pretendiam controlar. Para o colono martinicano Pierre Régis Dessalles, na década de 1780, as alforrias seriam "abusivas e perigosas em uma colônia onde teme-se que a raça dos libertos se torne maior que aquela dos brancos" (DESSALLES, 1847, p. 418-419). As medidas administrativas restritivas sobre a concessão de alforrias e aquelas que precarizavam a liberdade - por exemplo, a exigência de verificação dos títulos oficiais de alforria (CANELAS, 2020, p. 7-8) — foram alguns dos meios utilizados na Martinica para se tentar conter o crescimento da classe dos libertos e livres de cor.

O Código Negro de 1685 enunciava em seu 550. artigo que os senhores com mais de vinte anos poderiam alforriar seus escravos, sem que tivessem que justificar essa ação. Contudo, em 1711, o governador da Martinica, general Raymond Baltazhar Phélypeaux, infringiu tal lei, determinando que as manumissões deveriam ser autorizadas e registradas pelo Conselho Superior da colônia (ELISABETH, 1972, p. 140). Essa decisão de Phélypeaux foi motivada por um processo envolvendo a família La Pallu, a qual reclamava a posse sobre três mulheres negras. As irmãs Marie Castelet, Cathin Lamy e Babet Binture viviam como livres e tocavam um estabelecimento na vila de Saint-Pierre, que funcionava como taberna e estalagem. Desde 1704, procuravam oficializar sua situação e de seus filhos como "affranchis d'origine" (livres de nascença), argumentando que tinham nascido de pai e mãe libertos (PEABODY, 2005, p. 56-78; GRINBERG \& PEABODY, 2013, p. 27-33). 
Quando o general Phélypeaux assumiu o governo da Martinica, em 1709, tornou-se forte aliado da família La Pallu e escreveu ao governo metropolitano francês, tratando especificamente do caso daquelas três irmãs. Em sua correspondência, argumentou que o Intendente que havia oficializado a condição de livre de Babet Binture a última das irmãs a solicitar aos administradores da colônia o reconhecimento de seu estatuto - "não tomou conhecimento das leis do país entre brancos e negros, nem deu atenção ao grau pelo qual tal conduta poderia incitar a insolência dos negros" (citado em GRINBERG \& PEABODY, 2013, p. 29-30). Por conta da insistência de Phélypeaux, o governo metropolitano exigiu que o processo de Babet fosse revisto.

Histórias como essa, de indivíduos escravizados ou libertandos que batalhavam pela conquista e reconhecimento de suas liberdades, estimularam o governo francês a restringir a alforria. Em certa medida também por influência das ações do general Phélypeaux, o Conselho de Estado do Rei promulgou um decreto em outubro de 1713 que regulamentou as concessões de alforria em todas as suas possessões (DURAND-MOLARD, 1807, Tomo 1, p. 80-81, Arrêt du Conseil d'État du Roi concernant la liberté des esclaves). A partir dessa resolução, a manumissão de uma pessoa escravizada deveria necessariamente ser aprovada pelos administradores coloniais, independentemente da vontade senhorial. Outras leis foram promulgadas em 1736 (proibindo que filhos de mães escravizadas fossem designados como livres nos registros de nascimento ou de batismo), 1745 (imposto para obter o registro de alforria oficial, equivalente ao valor de um escravo), 1767 (restrição de alforrias legadas em testamentos sem autorização do governo da colônia), tornando os procedimentos para se obter a alforria oficial, controlada pelo estado colonial, cada vez mais minuciosos e custosos (CANELAS, 2017, p. 61-79).

Nesta análise, pretendo destacar, sobretudo, que o tema da alforria revela questões profundas que interligam raça e gênero. A historiografia francesa é quase unânime em afirmar que as primeiras alforrias concedidas no início da colonização 
francesa nas Antilhas foram auferidas pelos filhos "mulatos" dos "primeiros contatos sexuais entre europeus (brancos) e africanos (negros)", "das relações entre senhores e escravas ou entre servos (domésticos, capatazes, engagés) brancos e escravas" (LOUIS, 2011, p. 55). Todavia, essa noção sobre a "origem" do grupo de libertos e livres de cor, que vincula a formação inicial daquela classe ao nascimento e à alforria dos "primeiros mulatos", é bastante controversa. Um dos capítulos da tese do historiador francês Abel Alexis Louis é intitulado "A origem do grupo [dos livres de cor]: a libertinagem dos brancos e as primeiras alforrias" (LOUIS, 2011, p. 59). De certa forma, retoma, sem problematizar, o discurso de cronistas como os padres Jean-Baptiste Du Tertre e Jean-Baptiste Labat, alimentando a duradoura representação da liberdade vinculada à mestiçagem nas Américas.

Sob seu prisma de missionário católico e sua visão de homem europeu, Du Tertre escreveu um capítulo em sua crônica com o título "Do nascimento vergonhoso dos mulatos e sua condição" (grifo meu). Neste texto, principalmente as mulheres negras são tratadas com um escárnio grosseiro e preconceituoso na descrição do eclesiástico sobre a origem dos mulatos. Du Tertre descreve como um "crime" a união entre homens brancos e mulheres negras e ressalta que as crianças geradas desse tipo de relação eram produtos de uniões entre "diferentes espécies", comparando-as à origem das "mulas". Essa ideia, da origem "vergonhosa" dos mulatos, continuaria a impregnar os textos de cronistas e viajantes e documentos da administração colonial ao longo do século XVIII, sempre ligando essa questão às noções de concubinagem e libertinagem e, ainda, à alforria das mulheres negras e às pessoas livres de cor em geral:

\footnotetext{
Não poderíamos verificar melhor o provérbio que diz que o amor é cego que na paixão desregrada de alguns de nossos franceses que se colocam a amar suas negras, apesar do negrume de seus rostos, que as torna horrendas, e o odor insuportável que elas exalam, que deveria, na minha opinião, apagar seu fogo criminoso (...). As crianças nascidas dessas aproximações ilegítimas são comumente chamadas de mulatos em toda a América (...) fazendo, sem dúvida, alusão às mulas, porque essas pobres crianças são geradas de um branco e de uma negra, como a mula é produto de dois animais de diferentes espécies (DU TERTRE, 1667, p. 511-512).
} 
Du Tertre, quem viveu nas Antilhas francesas no começo da colonização, na década de 1640, narra em sua obra que os senhores tinham direito sobre as "crianças infelizes" que nasciam das uniões entre seus escravos (DU TERTRE, 1667, p. 504). Mas os filhos "mulatos", frutos do "crime" cometido por homens brancos que violentavam as mulheres escravizadas, eram isentos do "axioma do direito que dá ao filho a condição da mãe, o partus sequitur ventrem", sendo declarados livres para "punir o pecado de seus pais", os quais deveriam prover a criança até a idade de doze anos (DU TERTRE, 1667, p. 512-513). Já o sucessor de Du Tertre, o padre Jean-Baptiste Labat, narra que a premissa do partus sequitur ventrem foi instituída apenas em 1674, quando o rei reuniu as ilhas do Caribe sob seu domínio². Entretanto, segundo Labat, no início da colonização das Antilhas francesas, o governo colonial estabeleceu que os filhos "mestiços" de mulheres negras escravizadas e homens brancos seriam livres sob a condição de servirem os senhores de suas mães até a idade de 24 anos (LABAT, 1724, p. 37).

As controvérsias acerca da hereditariedade da escravidão nas possessões francesas foram dissipadas, todavia, com a promulgação do Código Negro em 1685, no qual os artigos 12 e 13 regulamentaram que a condição das crianças seguiria aquela do ventre que as levava, qual fosse o status do pai, e que elas seriam propriedade do senhor da mãe (DURAND-MOLARD, 1807, p. 43-44). Assim como Du Tertre, o padre Labat também enfatiza que "a libertinagem dos brancos com as negras" era "a fonte de uma infinidade de crimes" (LABAT, 1724, parte II, p. 40). Em seu texto, o crime da "libertinagem" é atribuído às duas partes, porém, rapidamente, ao longo do século XVIII, essa visão afetará particularmente a imagem da mulher negra ou "mulata" e sua experiência cotidiana.

Desde o século XVII, as relações inter-raciais e o lugar dos "mestiços" no sistema colonial e escravista foram considerados um problema. O artigo 9 do Código Negro condenava os homens

\footnotetext{
${ }^{2}$ Em dezembro de 1674, Luis XIV revogou o poder da Companhia das Índias Ocidentais sobre suas possessões nas Américas, estabelecendo seu completo domínio, com o Edit portant Révocation de la Compagnie des Indes Occidentales: et union au Domaine de la Couronne, mas não encontrei nenhuma menção ao princípio do partus sequitur ventrem nesta lei ou qualquer outra da década de 1670. MOREAU DE SAINT-MÉRY, 1784, p. 283-289.
} 
livres $^{3}$ que tivessem filhos com mulheres escravizadas, determinando uma multa de duas mil libras de açúcar aos transgressores. Ademais, se o homem livre (não proprietário) não fosse casado com outra pessoa durante a concubinagem com a mulher escravizada, ele deveria, ainda, se casar com ela "nas formas observadas pela Igreja", a escrava e os filhos seriam libertos e as crianças legitimadas. Caso os próprios senhores tivessem filhos com suas cativas, além da multa, seriam expropriados da escrava e das crianças, os quais nunca poderiam ser alforriados. Louis Sala-Moulins argumenta que essa medida jurídica se demostrou, muito frequentemente, condescendente com os homens brancos, os quais geralmente não tinham nenhum desejo de libertar as escravas das quais abusavam sexualmente, nem mesmo as crianças que nasciam destas relações abusivas (SALA-MOULINS, 1987, p. 108-109).

O Código Negro de 1724, aplicado apenas na Louisiana, proibiu tanto o casamento como a concubinagem entre brancos e negros (SALA-MOULINS, 1987, p. 109). Mesmo que essa disposição não tenha vigorado nas Antilhas Francesas, ela indica que a nobreza metropolitana e as elites coloniais estavam predispostas a restringirem o quanto pudessem relações inter-raciais e, geralmente, repudiavam aqueles homens brancos que se casavam com "mulheres livres de cor" (PIERRE-LOUIS, 2015, p. 202). Moreau de Saint-Méry os distingue em uma categoria à parte. Considerados mésalliés, isto é, que se casavam com uma pessoa de nível muito inferior, deveriam ser vistos como uma classe intermediária “entre brancos e gente de cor" (MOREAU DE SAINT-MÉRY, 1797, p. 99). Devido à ideologia discriminatória dominante, escolher se casar com uma mulher de cor privava o marido branco de ter acesso a postos oficiais nas colônias e aos títulos de nobreza, além de se expor ao desprezo e à reprovação da classe dos brancos (PIERRE-LOUIS, 2015, p. 215-227). Aparentemente, quando ocorriam, as uniões mais frequentes se davam entre mulheres livres de cor que possuíam "economias" e "petits blancs" - homens brancos que trabalhavam em ofícios artesanais, no exército, na marinha, ou pequenos negociantes e comerciantes (PEYTRAUD, 1897, p. 427; PIERRE-LOUIS, 2015, 276-301).

\footnotetext{
${ }^{3}$ É importante ressaltar que no final do século XVII, quando foi promulgado o Code Noir de 1685, pressupunha-se que os termos "homem livre" e "senhor" se referiam apenas a homens brancos.
} 
Nas instruções do rei aos administradores da Martinica de 1777, ao tratarem do tema da alforria, afirma-se que as liberdades concedidas na colônia resultavam frequentemente do "preço da libertinagem e da concubinagem", "escândalo" ao qual ainda se acrescentavam os "inconvenientes do perigo de se multiplicar os preguiçosos e os maus sujeitos", referindo-se aos filhos das relações íntimas entre homens brancos e mulheres escravizadas. Dessa forma, a "boa ordem" exigia que a alforria fosse permitida apenas com bastante "discrição" e que o governo colonial deveria autorizá-la apenas para "causas bem legítimas", ou seja, sobretudo para os homens que serviam no exército e nas milícias (DURAND-MOLARD, 1810, tomo 3, p. 294-295). Segundo o colono martinicano Pierre Dessalles, as restrições legais às alforrias tinham o objetivo de "prevenir os meios ilícitos empregados pelos escravos" para se tornarem livres, entre os quais destaca "a concubinagem dos senhores com suas escravas ou seu apego pelas crianças geradas de tal comércio". Nesse sentido, argumenta que "a esperança da liberdade leva quase sempre as negras a se prestarem às fraquezas de seus senhores" e, assim, tal esperança "lhes incentivam à libertinagem" (DESSALLES, 1847, p. 417-418).

Moreau de Saint-Méry, ao tratar da questão da alforria em São Domingos, ressalta que "várias negras" eram alforriadas porque elas tinham uma "complacência" por seus senhores que não beneficiava a moral e os costumes (MOREAU DE SAINT-MÉRY, 1797, p. 90). Parmentier, em Mémoire sur la législation de la Guadeloupe, escrita entre 1804-1805, afirma que "a cada cem alforrias, cinco, no máximo, tem um motivo louvável. As outras noventa e cinco foram dadas às concubinas favoritas e a alguns de seus filhos" (citado em RÉGENT, 2007, p. 186). Na década de 1840, Alphonse Maynard, francês de opiniões escravistas, afirmou em sua narrativa de viagem à Martinica que "ter um filho de um branco" era "para a negra objeto de seus desejos", porque significava entrar para a família e se tornar livre, "elevando-se" por meio de sua prole (MAYNARD, 1843, p. 130).

Em sua viagem às Antilhas Francesas, entre as décadas de 1760 e 1780, o médico naturalista Jean-Baptiste Leblond permaneceu um ano na Martinica. Durante sua estadia, hospedado em uma habitation ao norte da ilha, próxima à cidade de Saint-Pierre, ele foi convidado para uma 
festa de casamento realizada numa fazenda vizinha. Neste evento, o viajante observou a presença de "mulheres de cor" vestidas também de forma opulenta como as "damas" brancas, mas com costumes diferentes, certamente escravas, pois afirma que eram "criadas" (servantes) das damas presentes. Tinham os pés descalços, os cabelos presos em turbantes com belos lenços da Índia e várias joias de ouro, que o viajante francês presume serem presentes caros que os homens brancos lhes davam. Apesar da conclusão precipitada e preconceituosa de Leblond, outras fontes afirmam que os escravos "mais industriosos", principalmente as mulheres, empregavam parte de suas economias em suas vestimentas e acessórios, até com "um certo luxo entre várias mulheres escravas" (France. Ministère de la Marine et des Colonies, 1837, p. 5). Assim, não usavam joias porque necessariamente recebiam presentes dos homens brancos, mas porque fazia parte de seus costumes e, geralmente, elas mesmas procuravam adquirir o que desejavam, atitudes que frequentemente eram vistas como uma forma de petulância. Embora os homens brancos, presentes naquela comemoração em que se encontrava Leblond, interagissem apenas "furtivamente" com as mulheres negras escravas, o viajante declara que sua suspeita teria sido confirmada por uma "dama" (mulher branca) que se colocou a conversar com ele. Sem preliminares, a senhora foi logo afirmando que os "crioulos se livram a uma libertinagem terrível com estas negras e mulatas insolentes" — de acordo com o autor, expressão usada pela mulher com quem conversava —, "que lhes atraíam por todas as formas de sedução e que arruinavam suas saúdes e seus bolsos" (LEBLOND, 2000, p. 46).

Essa imagem sobre as mulheres negras e mulatas dominou os discursos coloniais ao longo do século XVIII e na primeira metade do século XIX. A ideia de que as mulheres negras e mulatas seduziam os homens brancos, principalmente os "petits blancs" e jovens, impregnou não apenas os discursos coloniais, mas também o imaginário dos franceses metropolitanos do século XIX, sendo mesmo representada de forma romantizada em uma canção popular da França, intitulada "Petit blanc":

Um petit blanc que eu amo / Chegou nessas paragens; / Sim, sim, era ele (...) / À pobre negra / Ele traz felicidade / Ela gostaria sem cessar / Pressioná-lo em seu peito / (...) Assim que cessa a sombra, / Que o céu está em chamas , / Você me diz: "Negra, / Descanse um pouco" / Você, bom, sempre o mesmo, / Nunca me bate / Tão linda é a sua boca, / Teu cabelo tão 
macio! / Quando minha mão os toca / Meu coração fica com ciúmes; / Seu olhar me encanta / Como o dia mais lindo / E sua voz comovente / Me faz morrer de amor ${ }^{4}$ (Letra de Boucher de Perthes, 1826, SÉGUR \& DUMERSAN, 1866, p. 30).

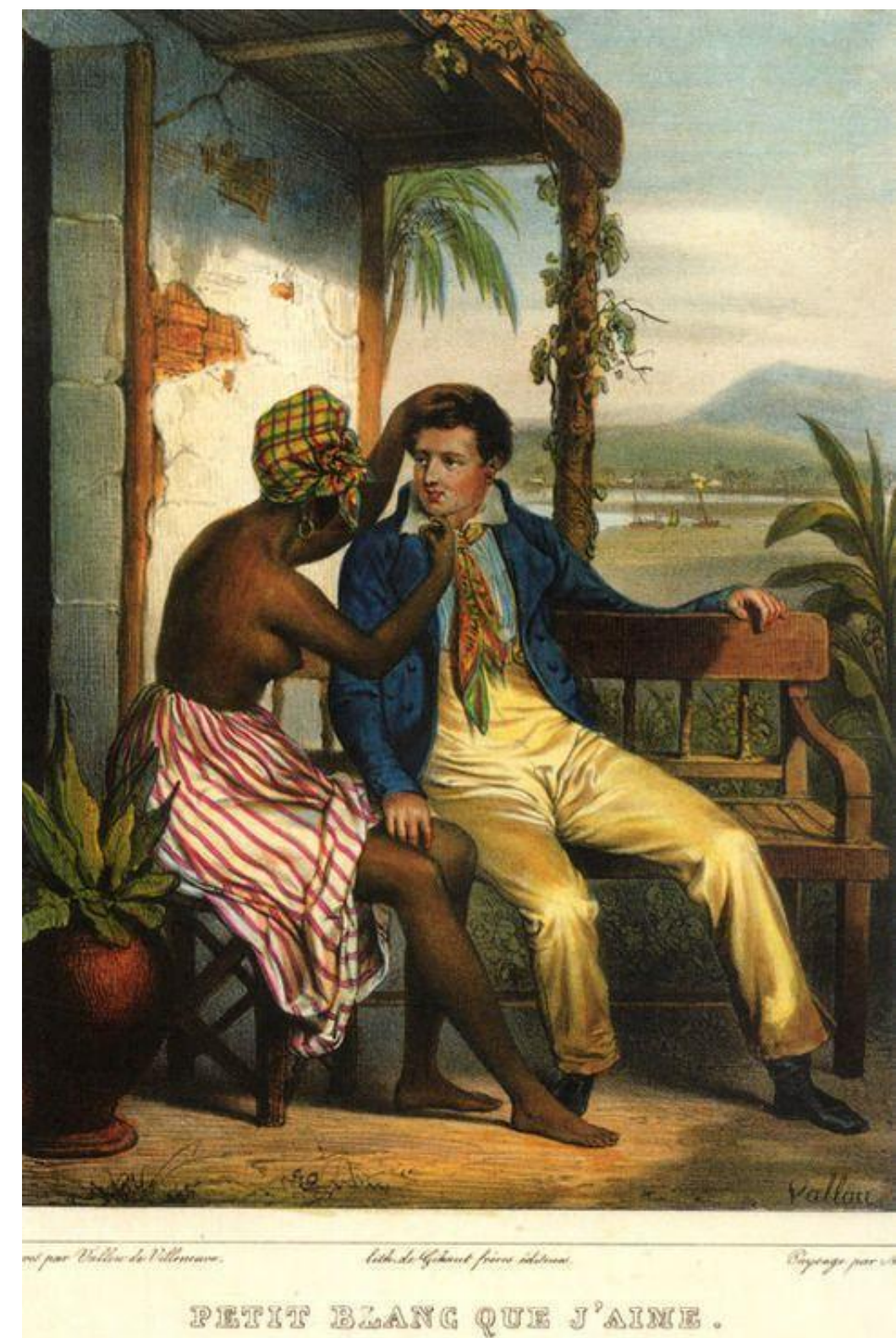

\footnotetext{
4 “Un petit blanc que j'aime / En ces lieux est venu; / Oui, oui, c'était lui-me (...) / A la pauvre négresse / Il porte le bonheur / Elle voudrait sans cesse / Le presser sur son cœur / (...) Sitôt que l'ombre cesse, / Que le ciel est en feu, / Vous me dite: "Négresse, / Reposez-vous un peu / Vous, bon, toujours le même, / Jamais ne me battez / Si belle est votre bouche, / Votre cheveux sont si doux! / Lorsque ma main les touche / Mon cœur en est jaloux; / Votre regard m'enchante / Comme le plus beau jour / Et votre voix touchante / Me fait mourir d'amour (...)".
}

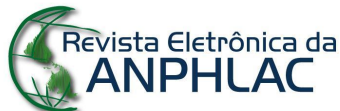

Revista Eletrônica da ANPHLAC, ISSN 1679-1061, № 31, p.152-187, Ago./Dez., 2021.

http://revista.anphlac.org.br 
Imagem: "Petit blanc que j'aime", Julien Vallou de Villeneuve, 1840,

Musée d'Aquitaine, Bordeaux (CAMARA \& DION, 2008, p. 167)

Esta canção provavelmente inspirou a imagem feita pelo pintor francês Julien Vallou de Villeneuve, em 1840, intitulada "Petit blanc que j'aime", na qual a mulher negra é representada de forma sensual, sedutora e entregue ao amor do jovem rapaz branco. A mulher negra segue invisibilizada na representação da fantasia dos homens brancos europeus, sensualizada, com destaque para seu corpo nu e sem rosto.

Até mesmo o célebre abolicionista francês, Victor Schoelcher, escreveu um relato sobre as "mulheres de cor" que exprime essa visão hegemônica. Em sua abordagem sobre a classe dos livres de cor — usa a expressão classe de couleur —, Schoelcher afirma que estes eram "quase todos sem família, frutos de uma concubinagem ou da libertinagem, mais ou menos abandonados por seus pais, pobres, mas necessariamente infestados dos vícios do país, recusando-se a trabalhar na terra, porque este é um trabalho de escravo" (SCHOELCHER, 1998 [1842], p. 190). Quanto às mulheres dessa classe, Schoelcher afirma que todas viviam "em concubinagem ou na devassidão, entre as quais os brancos vêm procurar suas amantes como em um bazar" e que assim eram levadas à prostituição. Em seu texto, o abolicionista conseguiu expressar uma imagem sobre as mulheres negras e libertas mais controversa que outras enunciadas por escravistas ${ }^{5}$ :

As mulheres de cor, por exemplo, que vivem todas em concubinagem ou na devassidão, entre as quais os brancos vêm procurar suas amantes como em um bazar, contribuem, certamente, com a sua libertinagem, a manter a depreciação da raça que elas desonram. (...) Não podendo esperar nenhuma consideração, sempre desprezadas, é natural que elas não façam nada para merecer o respeito. O preconceito gera o desprezo, o desprezo a desmoralização, e a desmoralização a prostituição; prostituição que legitima o desprezo pelo qual se mantém o preconceito. Um encadeamento assustador e cruel no qual o mal se explica pelo mal. As pobres criaturas, além disso, não poderiam escapar da ação deletéria das ideias do lugar onde elas são ensinadas. Os regalos da casta privilegiada as lisonjeiam, e elas preferem se entregar a um branco, velho, sem mérito e sem qualidade, que se casar com um sang-mêlé [mestiço]. Não faltam exemplos deste efeito deplorável da corrupção, que certos erros podem lançar sobre nossos espíritos (SCHOELCHER, 1998 [1842], pp. 192-193).

\footnotetext{
${ }^{5}$ Por exemplo, o viajante francês e defensor da escravidão, Alphonse Maynard, afirma quanto às mulheres livres de cor que "as mulheres desta classe tocam geralmente uma butique de faiança, novidades e especiarias, quando elas envelhecem; porque quando jovens estas criaturas parecer viver e respirar para amar, sonhar em se arrumar, aspirar a posse de joias ou de suntuosos lenços das índias" (MAYNARD, 1843, p. 114).
} 
O abolicionista francês visitou a Martinica e Guadalupe entre 1840 e 1841, com o objetivo de observar a situação do sistema escravista nas colônias francesas e foi hospedado por senhores brancos. De acordo com o abolicionista negro Cyrille Bissette, o fato de Schoelcher ter sido ciceroneado pelos colonos brancos em sua visita às ilhas teria resultado naquela exposição depreciativa sobre a classe dos livres e libertos, sobretudo em relação às mulheres, por influência da elite branca, pois expressava exatamente a visão desta classe sobre os livres de cor (BISSETTE, 1843, p. 5). A descrição feita pelo abolicionista francês sobre as mulheres é a parte do livro que mais teria provocado a indignação de Bissette, quem criticou vigorosamente a obra de Schoelcher de 1842, principalmente devido às observações sobre os livres de cor (BISSETTE, 1843, p. 61-66). Depois desse episódio, o rompimento entre o abolicionista negro martinicano e o abolicionista francês seria definitivo (SCHMIDT, 1994, p. 71-75; PÂME, p. 280-293).

A classe de livres de cor das colônias francesas, logo após a Revolução de Julho na França, demandava igualdade civil e política com os brancos, sem que houvesse qualquer diferença para os libertos, o que foi conquistado legalmente em $1833^{6}$. Contudo, batalhavam para que seus direitos fossem de fato reconhecidos ainda na década de 1840. Ademais, desde o início da Monarquia de Julho em 1830, já havia despontado, tanto entre os livres de cor que viviam nas colônias como aqueles que moravam na metrópole, articulações para garantir a alforria individual e oficial de libertos irregulares e dos escravos em geral, e mesmo demandas pela abolição da escravidão (CANELAS, 2017, p. 231-265). Ao refutar a obra de Schoelcher, Bissette argumenta que as declarações do "abolicionista" poderiam provocar "consequências funestas", e que os negros e mulatos sofriam já “o bastante com os esforços de seus inimigos naturais para dividi-los”, sem que

\footnotetext{
${ }^{6}$ Lei de 24 de abril de 1833 (Loi concernant l'exercice des Droits Civils et des Droits politiques dans les Colonies). Art. 1. Todas as pessoas nascidas livres ou tendo adquirido legalmente a liberdade, usufrui, nas colônias francesas, 1o. Dos direitos civis; 2o. Dos direitos políticos, sob as condições prescritas por lei. Art. 2. São revogadas todas as disposições de leis, éditos, declarações do rei, ordenações reais ou outros atos contrários à presente lei, e notadamente todas as restrições ou exclusões que tenham sido pronunciadas, quanto ao exercício dos direitos civis e dos direitos políticos dos homens de cor livres e dos libertos. A presente lei discutida, deliberada e adotada pela Câmara dos pares e pela dos Deputados, e sancionada por nós no dia de hoje, será executada como lei de estado (Bulletin des Actes Administratifs de la Martinique, 1833, p. 81-83).
} 
Schoelcher precisasse acrescentar sua contribuição à tal "divisão". Assinala, então, aos seus "irmãos negros e mulatos", que o livro de Schoelcher era uma "obra de divisão, cem vezes mais perigosa que todos os escritos dos colonos e de seus agentes" (BISSETTE, 1843, p. 70).

As representações sobre as mulheres negras e mulatas libertas que dominaram os discursos coloniais e a ideologia escravista, em geral, traçavam uma conexão direta entre conquista da alforria, libertinagem, concubinagem e mestiçagem, ignorando outros meios com os quais as mulheres poderiam construir seus caminhos para a liberdade, como a formação de um pecúlio a partir da produção excedente de gêneros alimentícios, do trabalho no ganho e do comércio de produtos variados (Cf. CANELAS, 2017, p. 138-161). Além disso, o olhar branco sobre as mulheres negras e a conquista da alforria procurava não observar, muito menos enfatizar, o papel das relações entre pessoas escravizadas e livres de cor, fossem elas de parentesco, proteção, trabalho ou mesmo de propriedade.

\section{Para além das narrativas sobre concubinagem e libertinagem: a conquista da liberdade sob uma perspectiva de gênero (Martinica, século XIX)}

Um dos primeiros historiadores franceses a escrever sobre a história da escravidão nas colônias francesas, baseando-se em documentos legislativos e administrativos dos arquivos coloniais, foi Lucien Peytraud, no final do século XIX. Em um dos capítulos de sua obra, Peytraud comenta sobre situações "honráveis" nas quais os escravos conseguiam obter suas alforrias. Estas ocorriam sobretudo quando os homens escravizados prestavam "serviços à causa pública", ou seja, quando lutavam como soldados contra os inimigos da coroa francesa que tentavam tomar as colônias, e quando auxiliavam na captura de escravos fugitivos ou na repressão a rebeliões escravas. Nestes casos, havia principalmente a intervenção da administração colonial e do governo metropolitano, pois muitos senhores não admitiam a alforria de seus escravos, mesmo nestas situações. No entanto, quando as mulheres conquistavam suas liberdades, segundo Peytraud, era sempre um caso de imoralidade:

Além dessas causas honrosas de alforria, devemos citar uma, que teve efeitos muito mais consideráveis, e não foi outra senão o fato da corrupção dos hábitos. [...] Tornar-se a escrava favorita ou uma das escravas preferidas do senhor, era, na maior parte do tempo, a ambição 
das negras. E quantos senhores, nesse caso, sabiam resistir a não libertar o objeto de sua fraqueza, a mãe de seus filhos e mesmo estas crianças? (PEYTRAUD, 1897, p. 405-406)

A partir de pesquisa sobre a Martinica nos anos finais da escravidão colonial francesa (1830-1848), procurei demonstrar que o acesso à alforria nas sociedades coloniais e escravistas francesas, sobretudo pelas mulheres, ocorreu sob um quadro sociocultural e político muito mais complexo que aquele quadro estereotipado apresentado por Peytraud. Por vezes, essa imagem foi reproduzida pela historiografia contemporânea sem uma análise crítica mais contundente acerca das questões de gênero, raça e classe que tocaram a conquista da liberdade por pessoas escravizadas nas Antilhas Francesas, ou, ainda, sem uma investigação mais precisa acerca dos dados disponíveis sobre as alforrias oficiais.

As taxas de alforria oficial no Caribe francês, sobretudo no século XVIII e início do XIX, foram historicamente baixas em comparação a outros espaços escravistas na América e no Caribe, como Brasil e Cuba, embora maiores que as taxas de alforria no Caribe inglês (Jamaica e Barbados) e nos EUA $^{7}$. A pesquisa acerca dos processos, características e sujeitos envolvidos no acesso à liberdade regular nas Antilhas Francesas antes de 1830 é um verdadeiro desafio. No período anterior à Monarquia de Julho (1830-1848), as alforrias oficiais dificilmente eram concedidas nas colônias francesas e, embora fossem controladas pelos governos coloniais, não são facilmente encontradas em documentos oficiais disponíveis nos arquivos.

Alguns historiadores encontraram em suas investigações alforrias concedidas em registros notariais da Martinica, especialmente em testamentos (ULRIC-GERVAISE, 2003; ELISABETH, 2003). É importante observar, contudo, que as alforrias testamentais não necessariamente se

\footnotetext{
${ }^{7}$ Por volta de 1800 e 1808, os libertos e livres de cor configuravam 41\% da população total de Minas Gerais e 18,8\% em São Paulo. Na mesma época, na Jamaica, representavam 2,9\% da população total, e em Barbados, 2,6\%. Nos EUA, neste mesmo período, eram 2,7\% da população total do Upper South, e $0,8 \%$ no Lower South. Em Cuba, por volta de 1774 , este grupo representava $20,3 \%$ da população total. Na Martinica, em 1802, os libertos e livres de cor representavam 7,1\% da população total, mas $40 \%$ da população livre, incluindo os brancos. Em São Domingos, por volta de 1784 , os livres de cor representavam $4 \%$ da população total, porém, quase $40 \%$ da população livre, incluindo os brancos. COHEN, \& GREENE, 1972, p. 3-10.
} 
convertiam em liberdades oficiais, devido à lei de 1764, que as restringiam, sendo que a liberdade apenas era regularizada com a outorga do governo colonial.

Apesar disso, a pesquisa de Léo Elisabeth acerca dos indivíduos que registraram as alforrias nos documentos notariais no final do século XVIII apresenta indícios que podem sustentar nossa argumentação, pois demonstram algumas características sobre os senhores e senhoras que tentaram alforriar seus cativos naquele período. Entre 1777 e 1793, Elisabeth encontrou 424 registros notariais onde a alforria de um escravo foi mencionada: 42\% foram registradas por homens brancos, $20 \%$ por mulheres brancas, $17 \%$ por homens livres de cor e $21 \%$ por mulheres livres de cor (ELISABETH, 2003, p. 423). Primeiramente, 58\% dos proprietários que alforriaram naquele período não eram homens brancos, característica da maior parte dos grandes senhores de escravos na Martinica. Considerando as restrições e dificuldades que as pessoas livres de cor provavelmente encontravam quando pretendiam alforriar escravos, especialmente no final do século XVIII (CANELAS, 2020), e ainda sua representação na população total da ilha naquele período ${ }^{8}$, a porcentagem de senhoras e senhores livres de cor que pretendiam alforriar seus escravos é muito significativa.

Nos anos finais da escravidão, durante o governo da Monarquia de Julho na França (1830-1848), a conquista do título de liberdade regular nas colônias francesas se tornou muito significativa devido às mudanças ocorridas nas leis e na política metropolitana em relação às possessões francesas de além-mar, juntamente às transformações encenadas nas próprias colônias (CANELAS, 2017, p. 213-285). Parte essencial de minha pesquisa se centrou em um exame de dados demográficos específicos acerca das alforrias outorgadas pelo governo da Martinica nas últimas décadas de escravidão nas colônias francesas. Entre 1831 e 1848, foram publicadas em torno de 435 decisões do governador portando a alforria de diversos indivíduos na Martinica (Arrêté du Gouvernement, portant affranchissement de divers individus dans la Colonie), nos principais periódicos da colônia, o Bulletin Officiel de la Martinque e o Journal Officiel de la Martinique.

\footnotetext{
${ }^{8}$ Em 1776, a população de livres de cor da Martinica era composta por 2.892 indivíduos, e a populações de brancos, 11.619; Em 1789, havia 5.236 livres de cor na colônia e 10.634 brancos.
} 
Embora essa análise quantitativa e qualitativa tenha sido uma parte fundamental deste trabalho historiográfico, procurou-se privilegiar, ainda, uma metodologia centrada na observação de micro-histórias de indivíduos ou de grupos familiares que auferiram suas alforrias oficiais ao longo da Monarquia de Julho. A partir disso, foi possível observar alguns elementos importantes e reveladores sobre os processos de conquista e concessão da liberdade nas Antilhas Francesas durante aquele período.

Para que essa metodologia fosse possível, em um universo de milhares de registros de alforria publicados nos periódicos oficiais da administração colonial da Martinica, foram analisados em torno de 1200 casos. Algumas informações não foram coletadas apenas nas fontes em que foram publicadas as alforrias oficiais. Certamente, se examinássemos apenas as informações sobre sexo, idade, cor da pele, profissão e local de moradia das pessoas alforriadas, seria possível coletar informações de um número muito maior. No entanto, era fundamental observar não apenas as pessoas alforriadas, mas também seus senhores. Os dados sobre os proprietários que alforriaram seus escravos foram considerados essenciais para procurar responder às questões colocadas por esta pesquisa. A mesma importância se aplica às relações de parentescos entre as pessoas escravizadas em uma mesma família, alforriados conjuntamente, e as ligações familiares entre escravos e senhores ou patronos. Compreender quem é o senhor que alforria, se é homem ou mulher, a qual “classe" pertence, isto é, se era branco ou livre de cor, são pistas importantes para compreendermos os padrões sobre a conquista da liberdade nas Antilhas Francesas, por meio de questões que englobam raça, classe e gênero. Essas referências nos auxiliam a pensar principalmente como os escravos construíram seus caminhos para a liberdade e como negociaram seu acesso à alforria oficial, sobretudo as mulheres, visto que elas conquistaram o maior número de alforrias no período.

Principalmente a "classe" dos senhores exigiu um empenho de pesquisa em outras fontes primárias e secundárias para que fosse determinada. O termo "classe" é utilizado aqui segundo a noção que era usada na época nas colônias francesas. Os grupos sociais eram divididos de acordo com uma suposta origem étnica, definida como "raça", entre indivíduos da "raça branca europeia", indivíduos da "raça negra africana" e indivíduos "das variedades de mestiços [sang-mêlés] 
provenientes do cruzamento destas duas raças". Ademais, eram divididos de acordo com o estatuto social (livre ou escravo), formando por fim três classes: a classe dos brancos, a classe dos livres de cor (gens de couleur libre ou affranchis) e a classe dos escravos (France, Ministère de la Marine et des Colonies, 1837, p. 1-5). Essas distinções influenciavam as interações sociais nas colônias, expressando uma complexa intersecção entre classe social e origem étnica.

Entre 1833 e 1847, foram outorgadas mais de vinte mil alforrias na Martinica, número extremamente atípico se comparado a outras épocas da história do Caribe francês. Desse quadro geral, as mulheres escravas foram os sujeitos que mais tiveram acesso à alforria naquela ilha, configurando quase $41 \%$ do total de liberdades oficializadas no período, seguidas pelas crianças, as quais representaram em torno de $35 \%$, e, por fim, os homens, por volta de $24 \%$. Primeiramente, é importante destacar que na Martinica, em 1835, por exemplo, em uma população escrava de mais de 78 mil indivíduos, as crianças até 14 anos formavam quase 30\% desse conjunto populacional, as mulheres acima da 15 anos, em torno de 37\%, já os homens, nessa mesma faixa etária, configuravam por volta de $33 \%$ dos indivíduos escravizados. Dessa forma, considerando que estas proporções se mantiveram mais ou menos as mesmas durante a Monarquia de Julho, havia uma quantidade maior de mulheres escravizadas adultas em toda a colônia, fenômeno que, provavelmente, também interferiu de alguma forma nos números das alforrias oficiais (CANELAS, 2017, p. 322-380).

Em segundo lugar, analisando não apenas os dados numéricos, mas também vários casos individuais e coletivos, o fato de as escravizadas adultas serem mais frequentemente alforriadas expressava, sobretudo, a importância da atuação das mulheres como mães, na organização dos lares e como arrimos de família, e mesmo as consequências de seu papel no mundo do trabalho escravo, tanto rural como urbano (CANELAS, 2017, p. 138-160). As análises sobre as manumissões ilegais e irregulares, principalmente as liberdades de savana, demonstraram o quanto as mulheres foram protagonistas na conquista de mais espaços de autonomia e de condições que favoreciam o aumento do pecúlio dos grupos familiares, apesar das situações de precariedade e da exploração escravista de seus corpos. 
Nas colônias francesas, a separação entre a "manumissão" (manumission) - o ato pessoal e privado de um senhor ao alforriar seu escravo, apoiando-se em seu direito de propriedade e levando em conta apenas sua vontade senhorial - e a "alforria legal" (l'affranchissement légal), a qual poderia garantir os direitos dos indivíduos libertos - foi induzida por uma sequência de leis e resoluções promulgados pelos governos colonial e metropolitano ao longo do século XVIII até as primeiras décadas do XIX. Desde uma ordenação real de 1713, uma carta de alforria "oficial” e válida ("alforria legal") somente poderia ser concedida pela administração da colônia. Os procedimentos para se ter acesso à alforria de um escravo ou escrava se tornaram minuciosos, controlados e custosos. Por conta disso, muitos proprietários acabavam por acordar a manumissão, sem necessariamente regularizarem a situação dos libertos e libertas, ignorando a autorização do governo e o imposto sobre a alforria - muito alto, quase o preço de um escravo (CANELAS, 2018).

Em razão dessa conjuntura, condições ambíguas de acesso à liberdade foram criadas, e mesmo toda uma série de termos que definiriam de maneira contraditória o estatuto das pessoas que não possuíam uma carta de alforria legal. Dessa forma, em variados documentos oficiais e privados, em diferentes ocasiões e épocas, termos como "soi-disant libre" (se dizendo livre), "libre de fait" (livre de fato), "libre de savane" (livre de savana), "liberté étrangère" (liberdade estrangeira) e "patronné" (patrocinado) foram usados para descrever esta condição. Abel Louis esclarece que todas estas denominações, "ainda que cada uma tenha um significado próprio", referem-se àqueles indivíduos que foram reagrupados sob o termo "livres de fato", os quais no direito colonial são sempre considerados escravos. No entanto, “curiosamente não são contabilizadas nos inventários e recenseamentos nem nesta categoria ou naquela dos livres de cor" (LOUIS, 2011, p. 153). Dessa forma, até 1831, os indivíduos que usufruíam dessas formas de "liberdade de corpo" nas colônias francesas, sem uma carta de alforria oficial, corriam o risco de serem reescravizados caso chamassem a atenção das autoridades. Como afirmou Louis Fabien na época, "eles não são livres, e eles não têm senhores; eles não são escravos, e eles não são cidadãos” (FABIEN, 1831, p. 9). 
Alexandre Moreau de Jonnes — viajante, militar e alto funcionário francês, responsável pelo Bureau de la Statistique générale de la France entre 1840 e 1851 - descreveu estas formas de liberdade irregular em sua obra Recherches statistiques sur l'esclavage colonial et sur les moyens de le supprimer (1842). Ele as define como um modo de "emancipação por resgate parcial", mas destaca sobretudo a possível experiência vivida por escravizados, originalmente trabalhadores domésticos, que moravam nos meios urbanos e negociavam a manumissão com seus senhores. Pagando-lhes um valor mensal, tornavam-se, assim, um "livre de fato", e Moreau de Jonnès indica que geralmente essa relação com seu patrono nunca era realmente quitada. Destaca-se em seu relato alguns dos trabalhos realizados pelas mulheres escravizadas para formar seus pecúlios:

É principalmente entre os escravos que moram nas cidades que se multiplica este tipo de
alforria [irregular]. (...) Estes escravos eram originalmente domésticos ligados à casa de seus
senhores; mas eles se afastaram dessa gradualmente, e se tornaram livres de fato pagando um
valor mensal (...). Os mais laboriosos entre eles realizam pequenos comércios, alugam-se a
estrangeiros para lhes servir, ou se engajam em obras públicas. As mulheres têm bodegas ou
fazem comércios ambulantes, levando, nas fazendas distantes das cidades, objetos de moda,
madras, ${ }^{9}$ que elas vendem com um ganho de $50 \%$, e às vezes o dobro. Quase todos estes
escravos podem acumular em pouco tempo o valor de sua alforria. Se o número daqueles que
usufruem destes recursos não é maior, é porque eles sempre esperam que uma emancipacãa
geral, absoluta e gratuita os dispensará de pagar qualquer valor. (MOREAU DE JONNĖS,
1842, p. 126-128)

Contudo, a conjuntura política da Monarquia de Julho proporcionou condições legais para que os livres de fato, livres de savana ou patrocinados conquistassem suas alforrias legais com a outorga do governo colonial. A elite colonial teve que amargar uma derrota com a promulgação da “Ordenação Real relativa às alforrias dos escravos", assinada em Paris em 12 de junho de 1832, a qual revogou leis anteriores que dificultavam sobremaneira o acesso à liberdade. Além disso, observou-se que as próprias famílias escravas, e mesmo redes de amigos libertos, provavelmente, ponderaram sobre a importância de resgatar do cativeiro as mães dos futuros filhos, irmãos, netos, sobrinhos e afilhados. No caso das mulheres livres de fato ou patrocinadas (liberdade irregulares e não oficiais), conseguir sua liberdade outorgada pelo governo colonial significava a oportunidade

\footnotetext{
${ }^{9}$ Madras era um tipo de tecido com cores vivas, fabricado em seda ou algodão, a princípio na Índia, na cidade de Madras, de onde vem o nome. Nas Antilhas eram utilizados para fazer vestidos, saias, mas principalmente lenços, que as mulheres negras usavam na cabeça, como turbantes. Ver Dictionnaire de l'Académie française, 6a. Edição, 1835, e Émile Littré: Dictionnaire de la langue française (1872-77), acessados em: artfl-project.uchicago.edu/node/17.
} 
de comprovar e garantir que seus filhos, nascidos depois de sua condição de liberta irregular, mesmo já maiores de idade, também pudessem conquistar suas alforrias regulares (CANELAS, 2018, p. 43-47).

$\mathrm{Na}$ amostragem analisada em minha pesquisa - em torno de 1200 alforrias oficiais, concedidas nas décadas de 1830 e 1840 -, as crianças até 14 anos representaram 42\% dos indivíduos libertos, as mulheres acima de 15 anos, 37\%, já os homens nesta mesma faixa etária, 21\%. Embora essas porcentagens da amostra sejam distintas daquelas obtidas sobre a totalidade de liberdades outorgadas pelo governo martinicano entre 1833 e 1847, demonstram-se bastante próximas. No conjunto de alforrias analisadas, um dado deve ser ressaltado, embora seja um tema controverso, mas impossível de ser ignorado, estando tão presente e frequentemente enunciado nas fontes e na bibliografia: as designações de cor da pele dos escravos libertos. $\mathrm{Na}$ amostra, entre aqueles indivíduos cuja classificação da cor da epiderme foi mencionada, em torno de 54\% tinham a pele mais escura (negros, câpres e grifs) e 46\% tinham a pele mais clara (mulatos, mestiços e quarteirões) ${ }^{10}$. Entre estes últimos, a grande maioria foi declarada como "mulato(a)". Esse quadro também destoa daquilo que geralmente os historiadores observam sobre a conquista da alforria em outros espaços de escravidão colonial no Mundo Atlântico. Frequentemente, afirma-se que os escravos afrodescendentes com a pele mais clara, sobretudo "mulatos", tinham mais chances de obter a liberdade.

No período estudado, os dados indicam que havia muito mais pessoas da classe dos "livres de cor" que demandaram a liberdade oficial a escravos e patrocinados na Martinica do que senhores

\footnotetext{
${ }^{10}$ Nas fontes referentes à Martinica, é possível observar uma linha de cor discriminatória expressa na seguinte nomenclatura de mestiçagem e de nuances da cor da pele: nègre(sse) (negro/a); câpre(sse); griffe; mulâtre(sse) (mulato/a); métis(se) (mestiço/a); quarteron(ne) (quarteirão/ona); mamelouk (mameluco). Suponho que o termo câpre (grafado como câbre no século XVIII) tenha relação com “cabra”, utilizado para designar indivíduos mestiços no Brasil, como pardo e mulato, nos séculos XVIII-XIX. No entanto, não há outras evidências para estabelecer tal relação com precisão; por isso, utilizo o termo em francês, câpre(sse), grafia mais usada no século XIX na Martinica. Não há tradução para griffe. De acordo com as pesquisas de Abel Louis e Jessica Pierre-Louis nos registros paroquiais (séc. XVIII) e do Estado Civil (séc. XIX) da Martinica, os termos comumente utilizados que se referiam às designações de cor da pele e de mestiçagem tinham esquematicamente o seguinte significado: mulato, descendente de negro e branco; câpre, descendente de mulato e negro; mestiço, descendente de mulato e branco; quarteirão, descendente de mestiço e branco; mameluco, descendente de branco e quarteirão; griffe, descendente de câpre e negro (LOUIS, 2011, 31; PIERRE-LOUIS, 2015, p. 196).
} 
brancos. Nesse sentido, se levarmos em conta aquele axioma sobre a frequência de relações conjugais entre escravas e seus senhores brancos, houve mais mulheres escravizadas que se relacionaram com homens livres de cor (pequenos proprietários). Contudo, as mulheres negras libertas também tiveram um papel fundamental na alforria das pessoas escravizadas ao longo da Monarquia de Julho, ou como patronas que solicitavam a liberdade oficial para seus patrocinados, ou como senhoras de escravos. Além disso, tanto as mulheres como os homens libertos se revelaram bastante atuantes nos processos de alforria de seus familiares que permaneciam na escravidão, auxiliando-os a juntar um pecúlio ou intermediar a solicitação de outorga da liberdade junto ao governo colonial.

$\mathrm{Na}$ amostra analisada nesta pesquisa para a década de 1830, 155 senhores e senhoras (ou patronos e patronas) alforriaram 357 pessoas escravizadas, e 195 livres de fato solicitaram suas liberdades oficiais sem o intermédio de um patrono/senhor. Proprietários identificados como pessoas livres de cor alforriaram 63\% dos escravos e escravas, já os brancos alforriaram 32\%. Os homens alforriaram mais que as mulheres: $62 \%$ dos escravos foram alforriados por indivíduos do sexo masculino e $38 \%$ por indivíduos do sexo feminino. Contudo, os homens livres de cor alforriaram em torno de $37 \%$ do total de escravos, enquanto que os homens brancos alforriaram $22 \%$. As mulheres livres de cor alforriaram $26 \%$ e as mulheres brancas $10 \%$ do total de escravos.

Deve-se levar em consideração que as mulheres brancas, geralmente, apenas poderiam atuar na negociação de propriedades, como a solicitação da alforria de escravos, quando eram casadas e com a permissão do marido - permissão frequentemente mencionada nos registros notariais - ou quando eram viúvas. Entre as 10 mulheres brancas que alforriaram seus escravos, 5 eram “damas", ou seja, casadas, e 5 eram “damas viúvas". Entre as 39 senhoras ou patronas livres de cor, 35 eram "demoiselles" (senhoritas), ou seja, solteiras, 2 "damas" e 2 "damas viúvas". Diferentemente das mulheres brancas, as mulheres livres de cor tinham uma atuação mais evidente e significativa na vida econômica da sociedade colonial e escravista, principalmente quando não eram casadas oficialmente (ROGERS, 2003, p. 40-51; LOUIS, 2015). 
$\mathrm{Na}$ amostra analisada para a década de 1840, 302 proprietários alforriaram 391 pessoas escravizadas. Nesse período, a grande maioria das pessoas que viviam como livres de fato e patrocinados já havia conquistado suas alforrias oficiais com a outorga do governo colonial, por isso, sua representatividade é muito reduzida no recorte feito para a década de 1840 . Os senhores identificados como livres de cor representam por volta de $71 \%$ do conjunto e os brancos $23 \%$. Assim como na amostra da década de 1830, na década de 1840 a quantidade de senhores livres de cor é majoritária, contudo, uma porcentagem maior foi observada no último período. Os homens brancos configuram $16 \%$ do total de senhores e em torno de $39 \%$ eram homens livres de cor. As mulheres livres de cor configuram $31 \%$ do total observado, ou seja, representam quase o dobro de homens brancos. As senhoras brancas representam apenas $7 \%$ do conjunto analisado, cifra similar àquela observada para a década de 1830 .

Em alguns registros foram mencionadas as relações de parentesco entre os senhores e seus escravos. Dessa forma, foi possível observar na amostra analisada que 93 senhores e senhoras livres de cor libertaram 112 escravas e escravos que eram seus parentes. Dessa forma, 57 indivíduos foram alforriados por mulheres livres de cor e 55 indivíduos foram libertos por homens livres de cor, que declararam o parentesco com o escravo ou escrava: 8 indivíduos foram alforriados pela avó; 8 alforriados pela filha; 6 alforriados pelo filho; 7 alforriados pela irmã; 3 alforriados pelo irmão; 34 alforriados pela mãe; 40 alforriados pelo pai; 2 mulheres alforriadas pelos esposos; 3 indivíduos foram alforriados pela tia e um indivíduo foi alforriado pelo tio. Uma das mulheres de origem africana contabilizada nesta amostra foi liberta por seu filho. Madeleine, "negra africana" de 63 anos, trabalhava como lavadeira em Saint-Pierre, era "escrava e mãe do senhor André", que trabalhava como pintor na mesma cidade, e alforriou sua mãe em agosto de 1840. Madeleine foi registrada com um sobrenome formulado a partir do nome de seu filho, Andréry (Arrêté du Gouverneur portant affranchissement de 7 individus libres de droit, Bulletin Officiel de la Martinique-BOM, 1841, p. 245).

A presença dos pais que libertaram seus filhos é bastante significativa, sendo sua representação neste conjunto até mesmo maior que das mães que alforriaram suas crianças. Alguns 
desses pais solicitaram a alforria oficial de mais de um filho, principalmente quando estes eram muito pequenos, situação menos frequente entre as mães que libertaram seus rebentos. Alphonse Burin, homem livre de cor que trabalhava como journalier (do ganho) em Saint-Pierre, alforriou seu filho Paul-Rosemond, menino negro de cinco anos, e sua filha Ursule-Marie-Louise, menina negra de um ano. Possivelmente, ambos estavam inscritos no inventário de tributação de Burin como "escravos", pois esta havia sido a forma com que foram designados no registro de alforria, e não como "patrocinados". Burin provavelmente não era casado oficialmente com a mãe das crianças. No registro de alforria consta que Ursule era "escrava e filha reconhecida de seu pai, senhor Burin" (Arrêté du Gouverneur portant affranchissement de 16 individus libres de droit, BOM, 1843, p. 299). Isso significa que não era filha "legítima", ou seja, não era fruto de um casamento oficial. Talvez a mãe das crianças fosse escrava e o pai liberto havia conseguido comprar e alforriar as crianças. Se foi este o caso, provavelmente não era o proprietário da mulher, porque, nesta situação, possivelmente a teria alforriado também.

Contudo, foi mais comum encontrar mulheres livres de cor que alforriaram filhos e netos numa mesma decisão do que senhores do sexo masculino. Em setembro de 1840, a demoiselle Calixte, costureira, moradora na cidade portuária de Saint-Pierre, alforriou sua filha Marinette Marie, 27 anos e designada como câpresse. Nascida no Carbet, habitava na mesma paróquia que a mãe e trabalhava também como costureira. Calixte alforriou ainda seus netos, os três filhos de Marinette, Marie: Clara (10 anos, mulata), Marie Oracia (6 anos, mulata) e Sylvestre (3 anos, mulato), todos nascidos em Case-Pilote (Arrêté portant affranchissement de 6 esclaves, en exécution de l'ordonnance du 11 juin 1839, BOM, 1840, p. 350-351).

Entre as mulheres livres de cor que alforriaram seus filhos, algumas haviam conquistado recentemente suas liberdades e suas crianças tinham nascido logo depois desse evento. A demoiselle Jeannine Lindar, marchande em Saint-Pierre, solicitou a alforria de seu filho Louis-Henry, câpre de um ano. Este caso é interessante porque Jeannine foi alforriada em 1840 e Louis-Henry nasceu, provavelmente, em 1842, pois sua alforria foi declarada em uma decisão de agosto de 1843, quando ele tinha em torno de um ano de idade (Arrêté du Gouverneur portant affranchissement de 16 
individus libres de droit, BOM, 1843, p. 299). Desse modo, quando Louis-Henry nasceu, Jeannine já estava liberta há dois anos. Por que, então, ela não pôde registrar seu filho como uma criança nascida livre?

Em muitos dos casos de mães alforriadas com seus filhos, os senhores são homens, frequentemente da classe de livres de cor. Por exemplo, em 1840, em Sainte-Marie, município predominantemente rural, no norte da Martinica, seu (sieur) Philippe alforriou seus escravos Julie Polly, "negra africana" de 25 anos, e os três filhos dela, Emmanuel, "câpre" de sete anos, Jean, “câpre" de quatro anos e Philippe Sufirin, "câpre" de um ano. Todos seriam registrados com o sobrenome "Pollyette", o qual visivelmente deriva do segundo nome da mãe. Não há indicação da profissão de Philippe, nem da profissão de Julie. Talvez Phillippe tivesse um ofício considerado "qualificado", como tanoeiro ou pedreiro, mas devido à ausência de indicação de uma profissão artesanal, e pelo fato de habitar em uma região predominantemente rural (Sainte-Marie), é bastante provável que ele tivesse uma porção de terras e cultivasse gêneros alimentícios. Há indícios de que os filhos de Julie Polly talvez fossem seus filhos também. O mais novo se chama "Philippe", como o senhor que o alforria. Na Martinica, esta situação, segundo Cousseau, ocorria mais frequentemente entre familiares (pais, tios, avós) ou quando a criança tinha o nome dos padrinhos (COUSSEAU, 2009, p. 613-615). A designação de cor da pele das crianças ("câpre”) indica que talvez fossem filhos de uma pessoa "negra" com uma pessoa considerada "mulata". Ademais, não há indicação do sobrenome de Philippe. Desse modo, muito provavelmente ele era um homem livre de cor, mas não foi possível certificar se havia e qual seria seu parentesco com Julie e suas crianças.

Há uma predominância de homens que alforriam grupos familiares, mas há também os casos em que as senhoras alforriam famílias, especialmente mulheres afrodescendentes. Demoiselle Marie Alexandrine, sem profissão, alforriou, em uma decisão de abril de 1840, Elianne dita Mélianne, câpre, 34 anos, e seu filho Louisy, mulato, 16 anos. Eles seriam inscritos nos registros do Estado Civil com o sobrenome "Ménivier", e não há indicação de suas profissões. Todos, tanto Marie Alexandrine quanto Elianne e seu filho, moravam em Saint-Pierre (paróquia do Mouillage). Marie Alexandrine certamente era uma mulher livre de cor, porém, não encontramos mais indícios 
para saber se havia alguma ligação de parentesco com Elianne ou se ela era apenas uma senhora que libertava seus escravos (Arrêté du Gouverneur en conseil, portant affranchissement de 17 patronés et 163 esclaves, BOM, 1840, p. 125-137).

Mulheres livres de cor e proprietárias de terras também alforriavam seus escravos. Um caso que se destaca é de demoiselle Solitude (sem indicação de sobrenome), "habitante propriétaire" no município de Gros-Morne, também uma paróquia predominantemente rural. Ela alforriou seis escravos, três mulheres com seus filhos, todas agricultoras, em três diferentes registros, um para cada núcleo familiar. Foram alforriadas Marie-Adeline, negra, 28 anos, "cultivant la terre" e seu filho, Avril, negro, sete anos (escolheram o sobrenome Patrol); Agnès dita Céline, negra de 25 anos, “cultivant la terre" (sobrenome Lafée); Agnès-Solitude, negra, 27 anos e suas duas filhas, Louise dita Adée, três anos, negra, e Marie-Luce, um ano, negra (sobrenome registrado, Cotap). Todas as escravas e seus filhos nasceram no Gros-Morne e lá habitavam, assim como sua senhora. Solitude não declarou nenhuma relação de parentesco com as escravas alforriadas. No entanto, as diferenças de idade entre Marie-Adeline, Agnès dita Céline e Agnès-Solitude possibilitariam que fossem irmãs e o fato desta última ter o nome "Solitude", indica alguma relação de parentesco, talvez espiritual, com a demoiselle Solitude. Este caso é interessante porque narra um fragmento de história de “pequenas proprietárias mulheres”, certamente livres de cor, agricultoras, que alforriavam seus/suas escravos. Na circunstância de Solitude, destaca-se o fato de ter alforriado três escravas mulheres, com seus filhos, sem homens ou companheiros (Arrêté du Gouverneur portant affranchissement de 55 esclaves et d'un patroné, en vertu de l'ordonnance royale du 12 juillet 1832, BOM, 1843, p. 203-207).

$\mathrm{Na}$ Martinica, as pessoas livres de cor em geral, quando eram senhores de escravos, possuíam um número reduzido de escravizados, fosse na área rural ou urbana (LOUIS, 2015, p. 455-472). Observando os dados analisados, foi possível inferir, ainda, que uma outra prática ocorria no caso dos libertos irregulares da Martinica. Provavelmente conseguindo uma manumissão irregular de um senhor branco, proprietário de escravarias maiores, a partir do momento que se tornavam livres de savana e que 
necessitavam da proteção de uma pessoa livre, a maioria procurava se aliar a pessoas livres de cor como seus patronos, alguns destes devido a relações de parentesco. Após as mudanças legislativas entre as décadas de 1830 e 1840, constatamos que as famílias escravas e libertas utilizaram como puderam os recursos jurídicos disponíveis para unirem seus membros na liberdade, a despeito da vontade dos senhores e da tutela do estado (CANELAS, 2017, p. 286-316; CANELAS, 2021).

\section{Considerações Finais}

A imagem depreciativa sobre a classe dos livres de cor, e substancialmente acerca da mulher de cor, fomentou ao longo do tempo profundos estereótipos que estiveram no centro de debates políticos, sociais e culturais nas colônias francesas e na metrópole. No entanto, é essencial destacar que o problema gerado em decorrência das relações íntimas entre mulheres negras e homens brancos não se centra em sua ocorrência, mas, principalmente, no contexto em que ocorreram e como foram observadas e descritas ao longo da história do Caribe francês. Ainda, sobre quem as teria narrado, ignorando, por um lado, as condições de violência e submissão vivenciadas pelas mulheres, e, por outro, distorcendo sua agência e suas estratégias de sobrevivência e autonomia.

Durante o período escravista, os relatos no tocante a relacionamentos sentimentais e sexuais entre mulheres afrodescendentes e homens de origem europeia foram quase sempre registrados e julgados por indivíduos brancos e do sexo masculino. Suas visões, presentes em narrativas de viagens, na literatura e em documentos oficiais, marcaram o imaginário sobre as mulheres afrodescendentes, escravas ou libertas, descritas como insolentes e lascivas, que seduziam os homens brancos de forma interesseira (LEBLOND, 2000, p. 46). Nesses registros, desde o século XVII, afirmava-se que as mulheres negras escravizadas preferiam a concubinagem com os homens brancos a escravos, na esperança de se tornarem libertas e terem crianças livres e mestiças. Esta pode ter sido, de fato, uma das estratégias utilizadas pelas escravas africanas e afrodescendentes para conseguirem se livrar do cativeiro.

No entanto, aparentemente influenciada pela profusão dessas narrativas, a historiografia francesa comumente generaliza a amplitude do fenômeno em questão. Ao observar os dados sobre a 
quantidade de mulatos livres recenseados nas fontes do século XVIII, por exemplo, nota-se que os historiadores geralmente inferem que a população de libertos das Antilhas Francesas era formada sobretudo pelos filhos de uniões ilegítimas entre senhores brancos e mulheres negras escravizadas. Christine Chivallon afirma que esse quadro expressa a "existência bem conhecida de uma estreita correlação entre a liberdade e a mestiçagem" (CHIVALLON, 2012, p. 89-90), embasando-se, em especial, nas conclusões de Frédéric Régent em seu estudo a respeito da escravidão e mestiçagem em Guadalupe (RÉGENT, 2004). Contudo, são raras as pesquisas que se fundamentam em análises demográficas qualitativas ou mais aprofundadas sobre as alforrias auferidas no Caribe francês. Embora esteja amparado em fontes secundárias quando se refere à Martinica e a São Domingos no século XVIII, Frédéric Régent afirma, precipitadamente, que não era raro uma "doméstica" conseguir sua liberdade e de suas crianças cujo "senhor é provavelmente o pai” (RÉGENT, 2007, p. 188). ${ }^{11}$

Contudo, muito provavelmente tais relações ocorriam sob a complexa situação de violência à qual as mulheres escravizadas, principalmente as domésticas, frequentemente estavam submetidas, como narrado em várias histórias abordadas por historiadores e historiadoras, e mesmo nos poucos relatos de mulheres negras escravizadas no Caribe no século XIX. Mary Prince viveu como escrava na ilha de Bermudas no século XIX, colônia inglesa na época. Em seu relato, narra como teria passado por diferentes proprietários, mas destaca-se em sua narrativa sua experiência como escrava doméstica. Nesse sentido, ela descreve como ela e outras mulheres escravizadas que trabalhavam na mesma função foram duplamente vítimas do senhor cruel e lascivo e de sua esposa, tão cruel quanto o primeiro, quem ademais sofria com o ciúme pelo marido que abusava das mulheres escravizadas em sua casa, descontando nelas sua ira (FERGUSON, 1997, p. 66-68).

Keila Grinberg aborda a história da escrava Liberata e sua família, vivida no Brasil na primeira metade do século XIX, e na qual as experiências de abuso sexual sofrido pela escrava e de sua alforria se cruzam. Liberata tinha dez anos quando foi comprada por seu senhor que, "escondido de sua mulher e filhos, passou a persegui-la pelos remotos e despovoados da região", até que "um

\footnotetext{
${ }^{11}$ Em seu livro sobre a história geral da escravidão nas Antilhas Francesas, os dados que analisa sobre Martinica e São Domingos foram obtidos nas obras de Léo Elisabeth (2003) e de John Garrigus (1988).
} 
dia ele conseguiu levá-la para os matos e, finalmente, a possuiu". Suas investidas se tornaram um hábito, mas Liberata relata, em sua ação de liberdade ocorrida entre 1813-1814, que "nunca permitia de bom grado os tratos ilícitos que com ela seu senhor tinha, por medo da senhora e de sua filha Ana". Contudo, acabou consentindo a mancebia, pois provavelmente não tinha muita escolha. Ademais, seu senhor havia prometido libertá-la assim que sua mulher descobrisse o caso. Liberata acabou parindo filhos de seu senhor, mas não foi por conta disso que obteve sua alforria, em 1814 . Apesar da ação judicial para conquistar sua liberdade, ela teria conseguido negociar a autorização de sua alforria provavelmente porque sabia de crimes cometidos por seu senhor e a filha legítima dele (GRINBERG, 2010, p. 5-9).

A historiografia, que tem se debruçado em intensos estudos sobre a documentação notarial e paroquial dos séculos XVIII e XIX para pesquisar as experiências dos livres de cor na Martinica, tem demonstrado que em mais da metade dos registros assentados, as pessoas dessa classe eram referidas genericamente como pessoas de cor. Além disso, deve-se considerar também que mesmo o termo mulato, por exemplo, provavelmente era empregado frequentemente para designar pessoas libertas ou que viviam como livres há gerações, embora suas classificações de mestiçagens pudessem ser indicadas como câpres, griffes, ou mesmo negros livres.

Arlette Gautier observou um caso raro de menção à paternidade de crianças escravizadas, filhos de uniões não oficiais, nos registros paroquiais ${ }^{12}$ de duas vilas da Martinica no início do século XIX, e demonstrou que apenas entre 4\% e 8\% das crianças provinham de genitores brancos. Conquanto seja uma amostra restrita de dados, Gautier busca destacar que as relações íntimas (e desiguais) entre homens brancos e mulheres negras escravizadas não eram majoritárias, mesmo que tivessem conduzido pouco a pouco a um processo de mestiçagem da população da ilha. Sobretudo, argumenta que tais relações raramente levavam à alforria das mulheres e de seus rebentos (GAUTIER, 2000, p. 986).

\footnotetext{
${ }^{12}$ Uma decisão do Conselho Soberano, de maio de 1758, determinou que nos registros tanto de livres como de escravos concernentes à criança que "não tenha nascido em legítimo casamento, não será feita nenhuma menção ao nome do pai"; isso afetava principalmente as crianças escravas, porque elas eram geralmente frutos de relações não oficiais. Cf. DURAND-MOLARD, 1807, tomo 2, p. 44-45.
} 
Stella Pâme considera que as crianças nascidas das uniões não oficiais entre homens brancos e mulheres de cor compuseram a maior parte da classe dos libertos até meados do século XVIII. Após esse período, observa-se que as relações endógenas entre pessoas de cor foram mais frequentes, uma tendência que se acentuou no século XIX (PÂME, 1999, p. 15). Certamente, existiram uniões entre homens brancos e mulheres negras no século XIX. Uma das mais marcantes, observada em minha pesquisa, foi a relação entre Xavier Bosc, francês que havia imigrado para a Martinica para trabalhar como gerente do engenho de açúcar da senhora Dariste, e sua escrava Pauline. Em janeiro de 1831, Bosc assentou junto a um notário da cidade de Saint-Pierre um registro de desistência de propriedade, uma forma de registro de manumissão, sobre Pauline e seus nove filhos, para que o governo da colônia lhes concedesse as cartas de alforria oficial. Bosc declara neste documento que estes escravos eram "livres de savana" (libertos irregulares) e que ele era apenas seu "protetor ou patrono". Entre os filhos de Pauline, os dois mais velhos, Adolphe, 27 anos, tanoeiro, e Adeline, 22 anos, lavadeira, foram designados como "negros" no registro; os outros sete mais jovens foram classificados como "mulatos" (ANOM - DPPC - Notaires: Damaret fils MAR/784, 20 de janeiro de 1831). Estes provavelmente eram filhos de Bosc. Contudo, o que torna essa história mais marcante é que logo depois do registro notarial mencionado, antes que a família escrava de Bosc pudesse obter a alforria oficial, eles foram envolvidos, assim como vários outros escravizados da fazenda Dariste, numa grande revolta de escravos que ocorreu em fevereiro de 1831 nas redondezas da cidade de Saint-Pierre (Martinica). No processo, afirma-se que Pauline era amante de Bosc, e ele foi um dos dois brancos incriminados por contribuírem com a revolta ${ }^{13}$. Tanto o casal como um de seus filhos, Volny, idade de 17 anos e profissão de pedreiro, e o filho mais velho de Pauline, o negro Adolphe, foram presos e acusados (ANOM - DPPC - SG, Martinica, carton 18, dossier 162). Todos foram absolvidos ao final do processo por falta de provas sobre seu envolvimento, mas não encontrei mais informações sobre o paradeiro de Bosc, Pauline e seus filhos após este período de prisão e processo criminal.

\footnotetext{
${ }^{13}$ Rebecca Schloss aborda a história dessa revolta e principalmente o envolvimento dos dois homens brancos, Bernard Xavier Bosc e Théodore LeChevalier. Em fevereiro de 1831, em torno de 300 escravos atacaram e incendiaram fazendas nas redondezas da cidade de Saint-Pierre, Martinica (SCHLOSS, 2007).
} 
A partir da Revolução Francesa, as lutas dos livres de cor por igualdade e contra a barreira racial, até então latentes ou simplesmente judiciárias, tornaram-se abertamente políticas (GAUTHIER, 2007, p. 63-151). Esse quadro também se intensificou por conta da Revolução em São Domingos (Haiti) e sua independência. Concomitantemente, o registro da cor, as medidas que limitavam os direitos civis e políticos das pessoas afrodescendentes, a legislação que restringia a concessão de alforrias e o princípio da superioridade social e racial da classe dos brancos foram percebidas como medidas essenciais para a manutenção do sistema colonial e da economia escravista, fortalecendo a segregação entre brancos e livres de cor. As relações íntimas consideradas inter-raciais, que ocorreram com maior frequência até o século XVIII, aparentemente, tornaram-se bem menos recorrentes a partir do momento em que a discriminação racial e as tensões políticas entre brancos e livres de cor se intensificaram nas Antilhas Francesas. Todos os indícios desse cenário histórico assinalam que as análises historiográficas sobre escravidão e liberdade devem ser acuradas sob uma perspectiva de gênero, antes de apontarem conclusões que conectem, muito reiteradamente, a liberdade dos afrodescendentes às situações de concubinagem e mestiçagem entre senhores brancos e mulheres negras escravizadas, reproduzindo, em certa medida, os discursos escravistas.

\section{Referências Bibliográficas}

\section{Fontes}

BISSETTE, Cyrille Charles Auguste. Réfutation du livre de M. Victor Schoelcher, intitulé: “Des Colonies françaises”. Paris: Breton, 1843.

Bulletin des Actes Administratifs de la Martinique, 1830-1833.

Bulletin Officiel de la Martinique, 1833-1847.

DESSALES, Adrien. Histoire Générale des Antilles. Série 1, Tome troisième: Histoire Législative des Antilles ou Annales du Conseil Souverain de la Martinique, par Pierre Régis Dessalles. Paris: Libraire-Éditeur, 1847. 
DU TERTRE, Jean-Baptiste. Histoire générale des Antilles habitées par les françois. Tomo II. Paris: Chez Thomas Iolly, 1667.

DURAND-MOLARD, Code de la Martinique, contenant les Actes Législatifs de la Colonies. Tomos 1- 3. Saint-Pierre, Martinique: Jean-Baptiste Thounens, 1807-1810.

France, Ministère de la Marine et des Colonies. Notices statistiques sur les colonies françaises. Paris, Imprimerie Royale, 1837.

GRANIER DE CASSAGNAC, Adolphe. Voyages aux Antilles françaises, anglaises, danoises, espagnoles, à Saint-Domingue et aux Etats-Unis d'Amerique. Premier Partie: Les Antilles Françaises. Paris: Dauvin et Fontaine Libraires, 1842.

LABAT, Jean-Baptiste. Nouveau voyage aux isles de l'Amérique, contenant l'histoire naturelle de ces pays, l'origine, les mours, la religion \& le Gouvernement des Habitans anciens \& modernes. Parte II. La Haye, Pays-Bas: Chez Husson e outros, 1724.

LEBLOND, Jean-Baptiste. Voyage aux Antilles. D'île en île, de la Martinique à Trinidad (1767-1773). 2a . Edição, apresentada e anotada por Monique Pouliquen. Paris, Éditions Karthala, 2000.

MAYNARD, Alphonse (pseudônimo Conde de La Cornillère). La Martinique en 1842: intérêts coloniaux, souvenirs de voyage. Paris: Gide Libraire-éditeur, 1843.

MOREAU DE JONNÈS, Alexandre. Recherches statistiques sur l'esclavage colonial et sur les moyens de le supprimer. Paris: Bourgogne et Martinet, 1842.

MOREAU DE SAINT-MÉRY, Louis-Élie. Loix et constituitions des colonies françoises de l'Amérique sous le Vent. Tomo 1. Paris: Chez Quillau, 1784.

MOREAU DE SAINT-MÉRY, Médéric Louis Élie. Description topographique, physique, civile, politique et historique de la partie française de l'Isle Saint-Domingue. Tomo premier. Paris: Dupont, 1797.

PEYTRAUD, Lucien. L'esclavage aux Antilles Françaises avant 1789, d'après des documents inédits des Archives coloniales. Paris: Librairie Hachette, 1897.

SCHOELCHER, Victor. Des Colonies françaises. Abolition immédiate de l'esclavage. Paris: Éditions du C.T.H.S, 1998 [1842].

SÉGUR, Noël \& DUMERSAN, Théophile Marion. Chansons nationales et populaires de France, accompagnées de notes historiques et littéraires. Paris: Garnier Frères, 1866

\section{Bibliografia}


CAMARA, Evelyne; DION, Isabelle; DION, JACQUES. Esclaves - Regards de Blancs 1672-1913. Aix-en-Provence, ANOM: Images en Manoeuvres Éditions, 2008.

CÂNDIDO, Mariana P. Concubinage and slavery in Benguela, c. 1750 - 1850". In: OJO, Olatunji \& HUNT, Nadine (orgs). Slavery in Africa and the Caribbean: a history of enslavement and identity since the 18th Century. London e New York: I. B. Tauris, 2012, p. 65-84.

CANELAS, Letícia Gregório. "Eles não são livres, e eles não tem senhores; eles não são escravos, e eles não são cidadãos": liberdade precária e clandestina no Caribe Francês (Martinica, século XIX). In: SECRETO, Maria Verónica; FREIRE, Jonis (orgs.). Formas de liberdade: gratidão, condicionalidade e incertezas no mundo escravista nas Américas. Rio de Janeiro: MauadX, Faperj, 2018, p. 43-70.

CANELAS, Letícia Gregório. "Livres de Cor" na Martinica: questões sobre raça e gênero no Caribe Francês (séculos XVIII -XIX). Revista de História, n. 179, 2020.

CANELAS, Letícia Gregório. Escravidão e liberdade no Caribe Francês: a alforria na Martinica sob uma perspectiva de gênero, raça e classe (1830-1848). 2017. Tese (Doutorado em História) Programa de Pós-Graduação em História, Universidade Estadual de Campinas, Campinas, 2017.

CHIVALLON, Christine. L'esclavage, du souvenir à la mémoire: contribution à une anthropologie de la Caraïbe. Paris: Éditions Karthala, 2012.

COHEN, David W. \& GREENE, Jack P. (orgs). Neither slave nor free: the freedmen of African descent in the Slave Societies of the New World. Baltimore \& London: The Johns Hopkins University Press, 1972.

COUSSEAU, Vincent. Population et anthroponymie em Martinique du XVIIe siècle à la première moitié du XIXe siècle: Étude d'une société coloniale à travers son système de dénomination personnel. Tese de Doutorado - História. Martinica: Université des Antilles et de la Guyane, 2009.

DURAND, Guillaume. Les noms de famille de la population martiniquaise d'ascendance servile. Origine et signification des patronymes portés par les affranchis avant 1848 et par les "nouveaux libres" après 1848 en Martinique. Paris: L'Harmattan, 2011

ELISABETH, Léo. La société martiniquaise aux XVIIe et XVIIIe siècles, 1664-1789. Paris: Karthala, 2003.

FURTADO, Junia Ferreira. Chica da Silva e o contratador dos diamantes: o outro lado do mito. São Paulo: Companhia das Letras, 2003.

FERGUSON, Moira (org. e introd.). The history of Mary Prince, a West Indian Slave, related by herself. Michigan: University of Michigan Press, 1997.

GARRAWAY, Doris. The libertine colony: creolization in the Early French Caribbean. Durham e Londres: Duke University Press, 2005. 
GAUTIER, Arlette. Les familles esclaves aux Antilles françaises, 1635-1848. Population, 55 ${ }^{\mathrm{e}}$. Année, n. 6, p. 975-1001, 2000.

GAUTHIER, Florence. L'aristocratie de l'épiderme: Le combat de la Société des citoyens de couleur, 1789-1791. Paris: CNRS Éditions, 2007.

GRINBERG, Keila. Liberata: a lei da ambigüidade - as ações de liberdade da Corte de Apelação do Rio de Janeiro no século XIX. Rio de Janeiro: Centro Edelstein de Pesquisas Sociais, 2010.

GRINBERG, Keila \& PEABODY, Sue. Escravidão e liberdade nas Américas. Rio de Janeiro: Ed. FGV, 2013.

HAYOT, Émilie. Les gens de couleur libres du Fort-Royal, 1679-1823 (1 $1^{\text {er }}$ partie). In: Revue française d'histoire d'outre mer, t. 56, n. 202, 1969.

LOUIS, Abel Alexis. Les libres de couleur en Martinique, des origines à 1815: l'entre-deux d'un groupe social dans la tourment coloniale. Tese de Doutorado em História, Université des Antilles et de la Guyane. Schoelcher (Martinica), 2011.

LOUIS, Abel Alexis. Marchands et négociants de couleur à Saint-Pierre (1777-1830): Milieux socioprofissionnels, fortune et mode de vie. Vol. 1 e 2. Paris: L'Harmattan, 2015.

PÂME, Stella. Cyrille Bissette: un martyr de la liberté. Martinica: Éditions Desormeaux, 1999.

PEABODY, Sue. Négresse, Mulâtresse, Citoyenne: Gender and Emancipation in the French Caribbean, 1650-1848. In: SCULLY, Pamela \& PATON, Diana. Gender and slave emancipation in the Atlantic world. Durham/London: Duke University Press, 2005.

PIERRE-LOUIS, Jessica. Les libres de couleur face au préjuge: franchir la barrière à la Martinique aux XVIIe-XVIIIe siècles. Tese de Doutorado em História, Université des Antilles et de la Guyane. Schoelcher (Martinica): 2015.

PRATT, Mary Louise. Os olhos do Império: relatos de viagem e transculturação. Bauru: EDUSC, 1999.

PRICE, Richard \& PRICE, SALLY (orgs.). Stedman's Surinam life in an Eighteenth-Century Slave society. An abridged, modernized edition of Narrative of a five years expedition against the revolted negroes of Surinam by John Gabriel Stedman. Baltimore, Maryland: The Johns Hopkins University Press, 1992.

RÉGENT, Frédéric. Esclavage, métissage, liberté. La Révolution Française en Guadeloupe, 1789-1802. Paris: Grasset, 2004.

RÉGENT, Frédéric. La France et ses esclaves: de la colonisation aux abolitions, 1620-1848. Paris: Bernard Grasset, 2007. 
ROGERS, Dominique. Réussir dans un monde d'hommes: les stratégies des femmes de couleur du Cap-Français. The Journal of Haitian Studies, vol. 9, no. 1, 2003, p. 40-51.

SALA-MOULINS, Louis. Le Code Noir ou le calvaire de Canaan. Paris: Presses Universitaires de France, 1987.

SCHLOSS, Rebecca Hartkopf. The february 1831 slave uprising in Martinique and the Policing of white identity. French Historical Studies, vol. 30, n. 2, 2007.

SCHMIDT, Nelly. Victor Shoelcher et l'aboliion de l'esclavage. Paris: Fayard, 1994

ULRIC-GERVAISE, Delphine. Les anglais à la Martinique, libres de couleur et affranchissements, 1793-1802. (Mémoire de Maîtrise d'Histoire, direction de Marcel Dorigny). Paris: Université Paris VIII, 2003.

WINTERS, Lisa Ze. The mulatta concubine: terror, intimacy, freedom, and desire in the black transatlantic. Athens (Georgia): University of Georgia Press, 2006. 